\title{
Men er det sant? \\ Et bredt forsvar for at man kan og bør diskutere sannhets- innholdet i religioner og livssyn
}

\begin{abstract}
Av Atle Ottesen Søvik
Burde det gis mer plass i religionsundervisningen til å diskutere hvorvidt påstander som hevdes i religioner og livssyn, er sanne? Denne artikkelen argumenterer for at elever både kan og bør diskutere sannheten i religioner og livssyn i større omfang enn det gjøres i dag. Fremgangsmåten er å gi en bred, samlet begrunnelse for dette, og artikkelen tar for seg fem typer innvendinger: epistemologiske, religionsvitenskapelige, pedagogiske, etiske og praktiske. De epistemologiske og religionsvitenskapelige innvendingene handler hovedsakelig om at man ikke (med rimelighet) kan diskutere religioners og livssyns sannhet, mens de øvrige argumentene hovedsakelig handler om at man ikke bør gjøre det.
\end{abstract}

Nøkkelord: Sannhetsspørsmål i religionsundervisning; religionskritikk

Atle Ottesen Søvik (f. 1977), professor i systematisk teologi, Det teologiske menighetsfakultet. Postboks 5144 Majorstuen, 0302 OSLO.E-post:Atle.0.Sovik@mf.no

\section{INNLEDNING}

Det finnes mange forskjellige grunner til å hevde at man i skolen verken kan eller bør diskutere hvorvidt religiøse påstander er sanne, og at det i så fall bør skje i beskjeden grad. Likevel skal jeg i denne artikkelen hevde at det finnes bedre argumenter for at man kan og bør diskutere sannheten i både religioner og livssyn, i større omfang enn det gjøres i dag. Hver for seg er de færreste argumentene jeg byr på nye, men jeg tror likevel det er nytt med en så bred, samlet begrunnelse som her tilbys i konteksten religionsundervisning i skolen. ${ }^{1}$

Tilnærmingen i denne artikkelen har fellestrekk med den tilnærmingen som har blitt forsvart av Andrew Wright (Wright, 2016). Han har forsvart en kritisk religionsutdannelse, der elevene skal diskutere sannhetspåstandene til ulike livssyn, basert på den vitenskapsteoretiske posisjonen kritisk realisme, som grovt sagt handler om at selv om vårt sinn former vår forståelse av verden, så finnes det en verden utenfor vårt sinn som vi kan oppdage noe sant om (Wright 2016: kap 2 og 8). Ifølge Wright er målet religiøs litterasitet (alfabetisme) - at elevene i større grad skal forstå sin grunnleggende plass i verden og få evne til å leve sannferdige liv med en ydmyk tilnærming til ulike livssyns opparbeidede visdom (Wright, 2016: 233 og 238).

1 Takk til Mikael Stenmark, Lars Laird Iversen, Trine Anker, Peder Gravem, Asle Eikrem, Espen Schjetne og Prismets redaksjon og anonyme fagfeller for innspill i arbeidet med denne artikkelen.

Prismet - IKO-Forlaget 2018

Tilgjengelig på https://journals.uio.no/index.php/prismet. Publisert under CC BY-NC 4.0. Fagfellevurdert 
En vanlig type innvendinger Wright har fătt, er at han reduserer religion til proposisjonelle påstander, og at han prioriterer rasjonalitet over følelser (Wright 2016: 223-224). Jeg tenker at elever selvsagt også bør lære om den siden av religion som er ikke-proposisjonell og emosjonell, men fokus i denne artikkelen er på den delen av undervisningen som dreier seg om sannhetspåstander, som også finnes i religion.

Selv om min vitenskapsteoretiske tilnærming faller inn under kritisk realisme vidt forstått, er den svært forskjellig fra Wright sin forståelse av både ontologi og epistemologi, og jeg skal utdype dette nærmere nedenfor. Jeg deler også hans mål om økt religiøs og livssynsmessig alfabetisme, men nevner mange andre fordeler med en slik tilnærming i denne artikkelen. Nedenfor tar jeg også opp andre innvendinger Wright har fătt.

I religionsvitenskapen er det et ideal å ikke mene noe om sannhetsgehalten i de religiøse overbevisninger som innehas av de man forsker på. Begrepet epoché brukes for å uttrykke at forskeren setter sine egne oppfatninger om dem i klamme. I den analytiske religionsfilosofien (som er min bakgrunn) er det derimot et ideal å finne ut hva som er sant og usant ved å diskutere hva som er best begrunnet, og forskeren argumenterer for sin oppfatning. I denne artikkelen foreslås det å trekke dette aspektet fra analytisk religionsfilosofi inn i skoleundervisningen.

Artikkelen tar for seg fem typer innvendinger: epistemologiske, religionsvitenskapelige, pedagogiske, etiske og praktiske, og de blir presentert i den rekkefølgen. De epistemologiske og religionsvitenskapelige argumentene handler først og fremst om at man ikke (med rimelighet) kan diskutere religioners og livssyns sannhet, mens de øvrige argumentene først og fremst handler om at man ikke bør gjøre det. Med en slik bredde sier det seg selv at artikkelen ikke vil gi noen dybdedrøftinger, men poenget er å vise hvordan man i hovedtrekk kan gi en samlet, sammenhengende begrunnelse, og så må enkeltpoenger drøftes videre i en forhåpentligvis påfølgende diskusjon.

\section{EPISTEMOLOGISKE INNVENDINGER: \\ Allmenn sannhet er et umulig mål å strekke seg etter}

Innenfor epistemologien foregår en debatt om $\mathrm{i}$ hvor stor grad menneskets sinn former forståelsen av virkeligheten: Er det mulig å ha sannheten som mål for teoretisk arbeid på den måten at man kan oppdage hvordan verden virkelig er, eller er enhver virkelighetsforståelse en konstruksjon man ikke kan komme på baksiden av eller sammenligne med andre med tanke på å finne ut hva som er sant? (Kuhn 1962)

Den posisjonen som gjerne kalles sosialkonstruktivisme eller antirealisme, kommer i mange former, men følgende beskrivelse presenterer noen vanlige 
argumenter: Det finnes ingen sannhet med stor S. Det finnes bare mange ulike og uforenlige perspektiver, som ikke kan integreres til én stor sannhet (Rorty 1995). Selv om det skulle finnes en sannhet med stor S, har alle mennesker bare tilgang til den fra sitt begrensede perspektiv. Dermed kan vi ikke sammenligne på tvers og si at noens beskrivelse er bedre enn noen andres. Kuhn gjør dette poenget med å si at paradigmer er inkommensurable (usammenlignbare). Alasdair MacIntyre gjør et lignende poeng av at tradisjoner ikke kan sammenlignes, som om det fantes et sted utenfor tradisjoner å sammenligne dem fra (MacIntyre 1988). Virkeligheten er noe vi konstruerer med vårt språk, så hva som er sant, er relativt til språket vi bruker for å uttrykke det. Om det så skulle finnes en sannhet med stor $\mathrm{S}$ på tvers av ulike tradisjoner, er det ingen grunn til å tro at vi mennesker vil nå den. Sannhet er et uoppnåelig mål, som man derfor ikke ser noen grunn til å sette seg (Rorty 1995).

Av denne typen argumenter for relativisme og mot sannhet, synes det å følge at man ikke legitimt kan sette seg som mål å diskutere ulike religioners og livssyns sannhetsinnhold, siden sannheten enten ikke finnes, eller fordi hva som er en god begrunnelse, bare kan vurderes innenfor hvert livssyn og ikke på tvers.

Kritisk realisme er en posisjon som aksepterer at sinnet former vår forståelse av virkeligheten, samtidig som det også finnes en virkelighet utenfor vårt sinn, som kan yte motstand mot våre konstruksjoner av den. Kritisk realisme er en vid sekkebetegnelse, så i det følgende skal jeg pakke ut en mer detaljert forståelse, som både inkluderer sinnets aktive forming av virkeligheten, samtidig som det gir mening å si at noen forståelser er nærmere sannheten enn andre. Presentasjonen bygger på den svært detaljerte teorien som er presentert $\mathrm{i}$ boken Structure and Being av den tyske filosofen L. B. Puntel (Puntel 2008).

For å besvare innvendingene som ble presentert ovenfor mot tanken om en allmenn sannhet, kan man argumentere på følgende måte. Når vi forstår noe, kan vi bare forstå det ved å integrere det i en større kontekst, så ingenting kan forstås som slik det er «i seg selv», uavhengig av kontekst. På den annen side er det heller ikke slik at enhver forståelse av verden er like god. Det finnes en virkelighet, og det finnes én virkelighet, nemlig summen av alt som finnes. Denne virkeligheten kan beskrives på ulike måter, og alle saksforhold vi sier verden består av, er også noe som mennesker må forstå i lys av en kontekst.

Noen forståelser av verden klarer å integrere flere saksforhold på en mer koherent (sammenhengende) måte. En god forståelse av sannhet er å si at det er den mest sammenhengende beskrivelsen av verden. Man kan da bruke koherens som et kriterium på sannhet, ved å si at den forståelsen som er mest koherent, er best begrunnet som nærmest sannheten - samtidig som man hele tiden må være åpen for at fremtiden kan by på en helt ny teori som er mer koherent enn hva vi hadde før. At en teori er mer koherent enn en annen, er altså ingen garanti 
for sannhet, men det beste kriteriet vi har. For det er opplagt at det finnes teorier som ikke er sanne, og at det finnes teorier som er bedre begrunnet enn andre, og vi trenger et kriterium for å skjelne mellom dem. $\AA$ s søke etter sannheten er nyttig og viktig selv om man ikke kan regne med å finne den endelige sannheten.

Så kan man tenke at et slikt kriterium ikke kan fungere i praksis, fordi folk med forskjellig bakgrunn, perspektiv og erfaringer vil ha ulike meninger om hvilke teorier som er mest koherente. Det er sant og å forvente at fordi folk sitter med ulike data, vil de også ha ulike meninger om hvilke teorier som får flest data til å henge best sammen. Samtidig er koherenskriteriet et detaljert verktøy som kan brukes ved uenighet. Hvis noe er inkonsistent, altså selvmotsigende (samtidig og med henblikk på det samme), så kan det ikke være sant. Noen data har stor tyngde i å være tett knyttet med andre data, slik at det er problematisk om en teori ikke klarer å integrere dem (for eksempel at jorda er eldre enn 6000 år). Man kan diskutere konkrete data eller erfaringer og diskutere hvor godt de integreres i ulike forståelser. Dette er slik teorier diskuteres mot hverandre i alle vitenskapelige disipliner.

Det at vi befinner oss i ulike paradigmer, har ulike perspektiver, tradisjoner, kontekster osv, taler ikke mot koherenskriteriet. For også perspektiver, tradisjoner, kontekster osv er deler av verden som kan sammenlignes med henblikk på koherens. Det betyr ikke at man kan regne med å gjøre en fullstendig sammenligning og komme frem til et endelig svar. Men det betyr at man kan gjøre fremskritt, og finne at noen oppfatninger er svært lite sannsynlige, andre er svært sannsynlige, og endre vurderinger av ulike oppfatninger underveis. Selv om ikke vi vil nå den endelige sannheten om alle ting, kan vi oppdage at det er mye som ikke er sant (at jorda er flat); at det er mye som er svært usannsynlig (at jorda ble til for 6000 år siden); at det er mye som er svært sannsynlig (at jorda er 4,6 milliarder år gammel), og så er det uansett interessant å finne ut hva som er best begrunnet i dag, og selv om vi ikke vet hva vi kan oppdage i morgen. Nettopp fordi vi bare har tilgang til sannheten fra vårt perspektiv, bør vi diskutere med andre for å lære mer om hvordan verden ser ut fra deres perspektiv, slik at man i sin forståelse også kan integrere hvordan ting ser ut fra ulike perspektiv.

\section{ReLigionsvitensKapelige inNVENDinger: \\ Det strider mot religionens egenart å diskutere sannhetsinnholdet med rasjonalitetskriterier}

Om man godtar at sannhet er et meningsfullt mål generelt, kan man likevel tenke seg at religiøse påstander er et unntak. Det kan være av flere grunner. Enten fordi religiøse påstander omhandler ikke-empiriske størrelser, eller fordi at hvis Gud finnes, så må Gud være bortenfor språk og tanke, slik at man ikke 
kan bruke vanlige rasjonalitetskriterier for å diskutere Guds eksistens eller om andre religiøse åpenbaringsbaserte påstander er sanne. Bare det at religiøse påstander sies å være basert på åpenbaring fra Gud eller guder, gjør at de ikke er vanlige hypoteser man kan teste med vitenskapelige kriterier. ${ }^{2}$ Om man skulle kunne diskutere sannhetsverdien til deskriptive påstander om verden i religioner, så inneholder også religioner mange etiske påstander, og mange vil hevde at etiske påstander ikke har sannhetsverdi, så derfor kan man ikke diskutere hvorvidt slike påstander er sanne for alle. Et eksempel på slik tenkning er C. L. Stevensons emotivisme (Stevenson 1944).

For å besvare innvendinger av denne typen, kan man argumentere på følgende måte: Også i filosofi, historie, teoretisk fysikk og mange andre fag diskuterer man ikke-empiriske størrelser, som indeterminisme, årsaksbegrepet, fri vilje, multiverset, naturlover, eller historiske hendelser. Måten man diskuterer det på, er å se hvor koherente andre data blir ved å anta en spesifikk hypotese om det aktuelle fenomenet som begrepet refererer til, for eksempel ett av begrepene nevnt $\mathrm{i}$ forrige setning. Akkurat det samme kan man gjøre med en konkret hypotese om Gud eller hva det skulle være av religiøse påstander. Og det er nettopp slik det foregår i seriøse analytiske religionsfilosofiske diskusjoner om Gud eller andre religiøse påstander, i artikler i anerkjente, vitenskapelige tidsskrifter og bøker utgitt på anerkjente universitetsforlag (Flint \& Rea 2008; Pannenberg 1991).

Når det gjelder at Gud og den religiøse virkelighet er bortenfor språk og tanke, så er det en viktig forskjell på hvordan språk og tanker er formulert i dag, og hvilket potensial språk og tanke har for å forstå verden i fremtiden. Språket utvider seg hele tiden og har et uendelig potensial til å uttrykke hva som helst, fordi man kan relatere uendelig mange tegn til hverandre på uendelig mange måter. At Gud er bortenfor språk og tanke, kan bare bety at Gud er mer eller annerledes enn hva mennesker har tenkt og sagt til nå. Det er selvmotsigende å påstå at Gud eller religiøse sannheter er bortenfor språk overhodet, for da bruker man språk til å beskrive en tanke, nemlig en grense hvor Gud er på den ene siden og språk på den andre, men alt dette befinner seg fortsatt innenfor språk og tanke, og er innholdsmessig ikke annet enn å si at det fortsatt er noe vi ikke vet eller har sagt om Gud (Eikrem, kommer).

Selv om en religiøs påstand sies å være basert på åpenbaring, så er påstanden om at religiøse påstander er basert på åpenbaring fra Gud eller guder, i seg selv en hypotese man kan teste med vitenskapelige kriterier når den blir spesifisert nærmere. Med «vitenskapelige kriterier» mener vi da om hypotesen får data til å henge bedre sammen enn alternative hypoteser. I debatter om Guds

2 Slike påstander er typiske for det som kalles negativ teologi. Asle Eikrem drøfter kritisk en del sentrale tenkere innenfor denne retningen (Eikrem, kommer). 
eksistens handler det ofte om at en gudshypotese bedre kan forklare naturlover, bevissthet, universets fininnstilling for liv osv, sammenlignet med alternative forklaringer. Man kan ikke måle Gud i et laboratorium, men svært mye vitenskap handler om data som ikke måles i laboratorier.

Når det gjelder hvorvidt etiske påstander kan være sanne og usanne eller ikke har sannhetsverdi, er det et spørsmål som diskuteres i metaetikken. Litt forenklet er det slik at innenfor metaetikken mener non-kognitivister at etiske påstander ikke har sannhetsverdi, mens kognitivister mener at de har det. Kognitivister er gjerne supernaturalister, naturalister eller ikke-naturalister. Supernaturalister mener normative påstander kan være sanne fordi de beskriver noe deskriptivt, nemlig Guds vilje. Naturalister mener at normative termer har et naturlig og deskriptivt innhold og derfor kan være sanne, for eksempel at det gode bare er det som skaper mest nytelse. Non-naturalister mener at verdier som godhet eller rettferdighet beskriver noe som faktisk eksisterer, for eksempel i en platonsk verden, og at normative påstander derfor kan være sanne. Kognitivisme dominerer blant moralfilosofer i dag uavhengig av livssyn (Parfit 2011). Også blant de etikere som ikke aksepterer kognitivisme, vil det være vanlig like fullt å mene at noen etiske påstander er bedre begrunnet enn andre. Det går dermed altså fint an å diskutere fordeler og ulemper med ulike etiske teorier uavhengig av hva man skulle mene om sannhetsspørsmålet i etikken.

Mot dette svaret kunne man innvende at det er urimelig å betrakte en religion eller et livssyn som en samling koherente påstander, når alle religioner og livssyn i realiteten er flytende fortolkningsprosesser med uklar struktur (Wright 2016: 223-224). Til denne innvendingen kan man si at dersom vi ser overordnet på de konkrete religioner og livssyn, så kommer de i mange varianter og endrer seg over tid. Like fullt bør individer som har en religion eller et livssyn, utfordres på hvor godt deres egen forståelse av deres eget livssyn henger sammen. Det er det kritisk tenkning handler om, og vil bidra positivt til den videre fortolkningsprosessen som alle religioner og livssyn gjennomgår. Nå kan man ikke forvente at elever skal ha et gjennomtenkt livssyn, og i praksis kan man ikke diskutere alle varianter i klasserommet. Men det man kan gjøre, er å diskutere sentrale påstander man finner i de fleste varianter av den aktuelle religion og livssyn, for eksempel Jesu oppstandelse, eller om Moses fikk de ti bud av Gud, eller om mennesket bare er fysisk. Så kan diskusjonen godt føre til at man blir klar over ulike alternative forståelser med argumenter for og mot hver av disse.

Mot dette igjen kan man innvende at religiøst språk er annerledes enn vanlige sannhetspåstander, enten fordi de har en spesiell type sjanger (metaforisk, analogt, eller noe annet) eller fordi de inngår i sitt eget unike meningsunivers. ${ }^{3}$ Dette vil jo da naturligvis være en viktig del av diskusjonen - altså hva er det

3 Takk til den ene av de anonyme fagfellene til artikkelen for denne innvendingen. 
den religiøse påstanden impliserer om verden. Der vil for eksempel noen si at skapelsesberetningen i Første Mosebok impliserer en ung jord og en skapelse på bokstavelig talt seks dager, mens andre vil si at det ikke gjør det, og en slik meningsklargjøring er en viktig del av diskusjonen. Når det gjelder at religiøse påstander inngår i sitt eget unike meningsunivers, gjelder det også at vi kan spørre om hva det impliserer om den verden vi lever i, og at det kan diskuteres ut fra samme resonnement som ble beskrevet ovenfor om diskusjon av ulike perspektiver, paradigmer, tradisjoner osv.

\section{Pedagogiske innvendinger: \\ Læreplanen for KRLE tilsier på mange punkter at religioners sannhetsinnhold ikke bør diskuteres}

Læreplanen for KRLE har en rekke punkter som synes à tilsi at man ikke bør diskutere om påstander i religioner og livssyn er sanne eller ikke (udir.no/klo6/ RLE1-02). Læreplanen sier for det første at elevene skal få kunnskap om religioner, ikke at de skal ta stilling til dem. Den sier for det andre at undervisningen ikke skal være forkynnende, men å argumentere for en at en religion er sann, er forkynnende. For det tredje sier læreplanen at undervisningen skal være objektiv, kritisk og pluralistisk, og presiserer videre at det betyr at den skal være saklig og upartisk. Dette synes å stå i strid med det å diskutere for og mot om religioner og livssyn er sanne. For det fjerde sier læreplanen at alle elever skal bli møtt med respekt for sitt syn, ikke at de skal få sin religion kritisert. Den sier for det femte at KRLE skal bidra til evne til dialog, men dialog er noe annet enn debatt. Dialog har som mål $\emptyset \mathrm{kt}$ forståelse, mens debatt har som mål overbevisning. For det sjette sier læreplanen at religionsundervisningen skal gi allsidig dannelse og toleranse. Dette skulle man tro at man best oppnår ved at elevene får kunnskap om religioner, og ikke ved å diskutere hvilken religion som er best begrunnet.

Mot denne tolkningen av læreplanen går det an å løfte frem en annen tolkning til st $\emptyset$ tte for at elevene bør diskutere sannhetsinnholdet i religioner og livssyn. Det forutsetter da at læreren må ta ansvar for at det i diskusjonen fremkommer argumenter både for og mot enhver religion og ethvert livssyn. For så lenge det både er argumenter for og mot av en viss kvalitet, er det ikke forkynnende i seg selv. I praksis kan det selvsagt forekomme forkynnelse eller maktmisbruk, men den faren er der uavhengig av om det legges opp til diskusjon eller ikke.

Undervisningen blir pluralistisk ved å gi alle aktuelle religioner og livssyn plass. Er det et livssyn elevene ønsker å diskutere, så bør det få plass. Undervisningen blir objektiv, saklig og upartisk når alle religioner og livssyn settes på samme linje som sannhetskandidater som hevder å ha rett. Undervisningen blir kritisk ved at det presenteres motargumenter til alle religionene og alle livssynene. Evne til kritisk diskusjon av etikk- og livssynsspørsmål er en svært viktig 
kompetanse, og en særdeles nyttig forebygger av ekstremisme, dersom man altså lærer seg å vurdere etiske og religiøse argumenter kritisk.

Den objektive og upartiske tilnærmingen forutsetter at læreren eller skolen ikke tar stilling til hvilke religioner eller livssyn som er best. Elevene må også få lov til å avstå å mene noe om det, samtidig som de - til forskjell fra læreren også får lov til å mene noe om det. Dette bør sies helt tydelig til elevene, at alle kan få teste ut argumenter uten å måtte stå til rette for dem eller avkreves sitt syn.

Når alle elever blir presentert for argumenter for sitt syn, bidrar det til at andre kan få $\emptyset \mathrm{kt}$ respekt for dem. Samtidig blir alle elever presentert for argumenter mot sitt syn, hvilket bidrar til at de kan forstå at andre kan ha grunner for å være uenig med dem. Det finnes gode argumenter mot alle religioner og livssyn (ateisme inkludert), hvilket burde mane enhver til litt ydmykhet. Erkjennelsen av at andre har grunner til å mene det de gjør og grunner mot å mene det du gjør, er essensielt for en faktisk opplevd respekt, til forskjell fra å bare si at man respekterer andres rett til å mene det de gjør, samtidig som man ikke har noen forståelse for at de gjør det.

Det er viktig at elevene får den innsikten at det for alle mennesker er slik at det er mange ting vi ikke vet at vi ikke vet. Videre at fordi man ikke vet hva man ikke vet, så vil typisk de som vet lite, være like overbevist om at de har rett, som de som vet mye - den såkalte Dunning-Kruger-effekten (Kruger \& Dunning 1999). Konkret må innsikten være at man gjennom diskusjoner i KRLE-faget bare får dekket en brøkdel av de fakta man måtte kjent til for faktisk å kunne gi en velbegrunnet vurdering av hvilken religion eller livssyn som er best begrunnet. En diskusjon i timen om et livssyn er dermed ikke å betrakte som at saken er ferdig snakket, men som at man har kommet litt lenger i sin kunnskap enn før. Også læreren bør si at det sannsynligvis er mye han/hun ikke vet at han/hun ikke vet av relevante fakta, slik at diskusjonen betyr at man har kommet lenger uten at det er grunnlag for å trekke en endelig konklusjon.

Dersom man skulle avdekke en selvmotsigelse i et sett med oppfatninger, så kan man si at noe må være feil, men det kan være mangel på presisjon, og at en distinksjon ville fjernet selvmotsigelsen. I det hele tatt er det nyttig å kjenne til de grunnleggende problemene med bekreftelse/verifisering og avkreftelse/falsifisering. Selv om en hypotese blir bekreftet, kan den være feil. For eksempel kan jeg ha som hypotese at treet foran meg er en bjørk og derfor vil miste bladene til høsten, og så bekreftes hypotesen ved at bladene faller av, men det er en eik. Og selv om en hypotese blir avkreftet, kan den være i hovedsak riktig, men ha en liten del som er feil, uten at man vet hvilken del det er. For eksempel var det slik at Newtons gravitasjonsteori ikke stemte med hvordan Uranus beveget seg, slik at altså Uranus sin bane avkreftet Newtons teori. Men feilen var at de ikke hadde 
oppdaget Neptun, så da man oppdaget Neptun, stemte Newtons teori igjen. Fordi verifisering og falsifisering ikke er endelig, så gjelder det som er skrevet ovenfor om at den beste teorien er den mest koherente, hvilket ikke utelukker at en mer koherent teori kan dukke opp i fremtiden.

Ofte løftes dialog frem som bedre enn debatt. Men debatt kan også ha som mål å vurdere argumenter uten å ha en endelig konklusjon. Da må det understrekes - som nevnt ovenfor - at man bare har dekket en brøkdel av alle argumenter som måtte vært vurdert for å lande på en velbegrunnet konklusjon om hvilket livssyn eller religion som er best begrunnet som sann. Skulle man nådd en slik konklusjon, måtte man sett på alle argumenter for og mot, og sammenlignet koherensen i hvert livssyn på tvers. Selv om man altså vil være langt fra et endelig svar, kan man komme lenger i forhold til der man er i å vurdere begrunnelser og å utforske videre. Da gir debatt $\emptyset \mathrm{kt}$ forståelse - man må bare ha bevisstheten om at man ikke er i mål når det ringer ut til friminutt.

A diskutere religioner og livssyn gir viktig dannelse, fordi man både får $\emptyset \mathrm{kt}$ forståelse for egne verdier og andres verdier, samtidig som man trolig tilegner seg nye verdier. Dette er tanken bak Thor Ola Engens modell om integrerende sosialisering, der elever både får bekreftet sin identitet ved å lære om eget livssyn, samtidig som det foregår en resosialisering og dannelse ved å lære om andres (Engen 1994). Det er også en sentral tanke i Robert Jacksons tolkende tilnærming til religionsundervisningen at eleven får eksistensiell hjelp til egen livstolkning (Jackson 1997 og 2004). Det å kunne diskutere livssyn er dannende og gir en metakulturell kompetanse ved at man făr kjennskap til andres livssyn og deres begrunnelser, jf. hvordan Habermas har tatt til orde for religiøse begrunnelsers legitime plass i det offentlige ordskiftet (Habermas 2006). Økt kunnskap gir også $\emptyset \mathrm{kt}$ toleranse. Ved å lære seg å diskutere vanskelige spørsmål på en saklig måte lærer man å leve respektfullt sammen tross uenighet om verdier.

\section{ETISKE INNVENDINGER: \\ $\AA ̊$ diskutere religioners sannhet i klasserommet skaper pro- blemer for elever med minoritetsoppfatninger}

Det er særlig to etiske innvendinger som skal drøftes her. Den første er at å diskutere sannhetsgehalten i religioner og livssyn er et sårbart tema hvor det lett blir konflikt. Det er en stor påkjenning å diskutere spørsmål som kan ha store eksistensielle konsekvenser hvis man skifter mening, så derfor kan man argumentere for at vi bør spare elevene for den belastningen. Noen kan bli svært provosert av at andre kritiserer deres livssyn, og det kan skape unødig bråk i klassen. 4

4 Dette er den innvendingen jeg hører fra flest religionslærere når de forklarer hvorfor slik diskusjon får lite eller ingen plass. 
Den andre innvendingen er at en diskusjon om livssyn og religion lett kan bli en urettferdig konflikt. Kristendom vil ha en urettmessig fordel i diskusjon mellom religioner, siden elevene făr mye mer kunnskap om kristendom, mens minoritetskulturer kan føle seg overkjørt i en diskusjon der majoritetslivssyn vil ha flere forsvarere (Bouras 1996). Spesielt uvanlige religiøse oppfatninger vil være ekstra sårbare i diskusjoner med andre. ${ }^{5}$ I tillegg kommer det asymmetriske maktforholdet mellom lærere og elever, som gjør at lærere kan overkjøre elever med sitt eget syn i presentasjonen av argumenter for og mot ulike religioner og livssyn. Peder Gravem argumenterer for at KRLE-fagets objektivitet tilsier at lærere ikke kan la egne overbevisninger styre undervisningen (Gravem 2004: 392). I tillegg kan det være mange som ikke har noen spesielle oppfatninger, men heller bare en diffus tro eller et usammenhengende livssyn, og som derfor kan føle seg marginalisert i debatter om livssyn.

Når det gjelder sårbarheten i temaet, er det sant at eksistensielle spørsmål har betydning og at læreren bør være var for dette i diskusjonen. Det faktum at eksistensielle oppfatninger betyr mye for oss og at vi nødig skifter mening, bør tematiseres før man kan få til en religionsdiskusjon. Noen viktige punkter i en slik tematisering er som følger: Alle mennesker er i utgangspunktet interessert i å få bekreftet sine oppfatninger, og ikke interessert i å få dem avkreftet. I et morsomt eksperiment ble en stor gruppe mennesker presentert for noe som så ut som veldig seriøs forskning som tilsa at det var farlig på lang sikt for kvinner å drikke mye kaffe. Alle trodde på det, bortsett fra de kvinnene som drakk mye kaffe, som var mye mer skeptiske - sannsynligvis fordi de ønsket å fortsette å drikke kaffe (Mele 1995: 88).

Mennesker er opptatt av trygghet. Det er naturlig nok, siden over lang evolusjonær tid vil de som er opptatt av trygghet, overleve bedre enn de som ikke bryr seg om trygghet. Identitet gir forutsigbarhet, som igjen gir trygghet, så derfor $\emptyset$ nsker mange bekreftelse på sin identitet. Livssyn er knyttet til sentrale eksistensielle spørsmål knyttet til ens identitet, hvilket for mange også handler om liv etter døden, om en Gud som er nær og kan gi trøst, om rettferdighet, mening, håp og mye annet.

Mange vil derfor i utgangspunktet være veldig interessert i å få sitt livssyn bekreftet, og kan ha stor motstand mot å få det kritisert. Man kan bli svært sint eller såret av å få sitt livssyn kritisert. Samtidig vil de fleste også være interessert i hva som er sant, og i det minste ikke ønske å tro på noe som det faktisk finnes gode grunner mot, som de ikke kjenner. For mange er det svært spennende og interessant om det kan lages en arena med forståelse om at ingen har fasiten, men vi legger på bordet argumenter både for og mot alles livssyn.

5 Espen Schjetne siterer Jeff Spinner-Halev sin argumentasjon for at truede kulturelle minoriteter bør få hjelp til å overleve (Schjetne 2014, med referanse til Spinner-Halev 2000). 
Det er ikke gitt at dette er mulig i alle klasser. Men det er ikke tvil om at samfunnet hadde hatt bruk for samfunnsborgere med evne til å diskutere saklig og kritisk verdispørsmål hvor det er stor uenighet. Skolen er en veldig god arena for å kunne øve på dette tidlig i møte med andres oppfatninger. For det er jo ikke gitt at det er bedre å la være å diskutere. Mange strever allerede bevisst eller ubevisst med konsekvensene av sitt implisitte eller eksplisitte livssyn, og kunne hatt stor hjelp av å møte argumenter for å tenke annerledes. Om noen får oppfatninger som er bedre begrunnet, så er det også verdifullt.

Kanskje kan det dempe opplevelsen av å bli kritisert å snakke mer generelt om grunner for og mot enn å snakke om argumenter for og mot sannhet. Istedenfor motargumenter eller innvendinger kan man eventuelt også kalle det utfordringer. Det viktige er øvelsen i evnen til kritisk tenkning.

Den andre innvendingen var at det lett kan bli en urettferdig debattsituasjon $\mathrm{i}$ klassen, og at kristendom kan få urimelige fordeler ved å være majoritetsreligion i Norge. Nå betyr jo dette at elevene får da også grunnlag for flere argumenter mot kristendom, ikke bare for. Det er ellers rimelig at det undervises mer om majoritetskulturen, siden også de med minoritetskulturbakgrunn har større behov for å kjenne mer til majoritetskulturen (Gravem 2004: 402). Minoritetskulturene vil få presentert argumenter for sitt syn, og argumenter mot majoritetslivssynene. Dette burde gi minst like god mulighet for $\emptyset$ kt respekt sammenlignet med at grunner ikke tematiseres i det hele tatt. I en multikulturell setting er det viktig at alle har mangfoldskompetanse, og man forstår andre bedre når man også forstår grunner til at de tenker og handler som de gjør.

Det er alltid en fare for at lærere kan misbruke sin makt, men det er ikke noe med faget som legger opp til det, så lenge læreren er bevisst sitt ansvar om å komme med saklige argumenter for og mot alle syn. Det bør også være lærebøker og informasjon om nettsider som presenterer gode argumenter for og mot, og som elevene kan lese selv. I praksis kan en lærer likevel misbruke sin makt, men fare for maktmisbruk finnes i alle sammenhenger uansett, og er dermed ikke et godt argument mot at et bestemt tema skal på dagsorden. Problemet må heller behandles slik det ellers gjøres, og i denne konkrete saken ville det være naturlig at det ble tematisert hvilken makt læreren og klasseflertallet har i diskusjoner om livssyn.

Samtidig er det klart at når et sårbart tema kommer på dagsorden til forskjell fra ikke å være det, så skaper det en arena med økt fare for maktmisbruk. Men hvis det er en arena hvor det gis gode retningslinjer for maktbruk, kan det også bidra mot maktmisbruk knyttet til elevers livssyn i andre sammenhenger. Elevers forhold til egen og andres tro inngår uansett i maktrelasjoner, men ved å lære å diskutere det saklig i skolen, kan det legges til rette for bedre bruk av makt og mer makt til svake. 
Når det gjelder elever med sære oppfatninger, så kan man argumentere for at det er viktig med gruppepluralisme i samfunnet, slik at disse får litt beskyttelse for sine standpunkter. Men det er også viktig at rasjonalitet er en verdi samfunnet kan samles om. Det er andre hensyn som er viktigere enn å forsvare åpenbart problematiske oppfatninger. Det kan ikke være et mål med utdannelse at ingen skal endre oppfatninger.

Når det gjelder elever som bare har diffuse livssyn, så vil det i praksis være sentrale påstander som diskuteres, og ikke hele livssyn, og da vil trolig mange flere ha en oppfatning av hva de mener om de enkelte påstander. Men i mange tilfeller vil det også være mange som ikke vet hva de mener om en sak. Da kan de få prøve ut argumenter for og mot, eller bare høre på argumentene som presenteres. Ingen skal avkreves sin oppfatning, og det bør sies eksplisitt at man kan få teste ut argumenter uten å måtte stå for dem. Istedenfor å presentere et argument ved å si «Jeg mener ... (argument)», så kan man spørre «Hva kan man svare hvis noen sier ... (argument)»? Et praktisk grep er også at hver elev bør rette sitt argument til læreren, og ikke snakke til eller om medelever.

\section{Praktiske innvendinger:}

\section{$\AA ̊$ diskutere religioners sannhet på en god måte krever for mye av både lærere, elever og lærebøker}

Når jeg har bladd gjennom de vanligste lærebøkene som brukes i KRLE, så ser jeg at det finnes lite argumenter for og mot om ulike påstander i religioner og livssyn er sanne, selv om det er spor av det, særlig i filosofidelene. Dette inntrykket bekreftes av bøker skrevet om lærebøkene (Skrunes 2010). Dersom lærere skal klare å presentere viktige argumenter for og mot ulike påstander i ulike livssyn, så er det en krevende jobb, som vil gå på bekostning av andre ting. Det er fordi vanlige argumenter om Guds eksistens, verdens tilblivelse, mirakler, liv etter døden osv, ofte trekker inn data fra mange forskjellige vitenskaper, som fysikk, kosmologi, evolusjonsbiologi og hjerneforskning. Det er heller ikke gitt at elevene vil være i stand til å vurdere så kompliserte spørsmål som sannhetsgehalten til religioner og livssyn. ${ }^{6}$

At det er komplisert, kan synes å tale mot at det skal inn allerede i grunnskolen, men det går jo an å begynne, siden dette er argumenter mange ellers møter på internett eller hos Richard Dawkins. Det burde absolutt være fruktbart for elever å diskutere for eksempel det ondes problem, verdens skapelse, liv etter døden, eller noen av argumentene for og mot Guds eksistens. Gunnar Skirbekk argumenterer nettopp for at man i religionsundervisningen $b ø r$ velge ut noen slike sentrale temaer og diskutere hvordan de løses i ulike livssyn (Skirbekk 2011).

6 Andrew Wright sier at kompleksiteten i spørsmålet om livssyns sannhet, er en de vanligste innvendingene han får mot å skulle diskutere det (Wright 2016: 223-224). 
Det finnes mye aktuelle argumenter for og mot, publisert i bøker, artikler og på internett. En lovende kandidat til å være et samlet nettsted er religioner.no som nylig har lansert prosjektet «Uenighetens fellesskap» der representanter for en lang rekke livssyn svarer på en liste med 50 spørsmål stilt dem fra religioner.no. ${ }^{7}$ Om det skulle bli en $\emptyset \mathrm{kt}$ trend med livssynsdebatt i skolen, vil religioner. no sikkert kunne stille med gode ressurser.

Religionsfilosofi er et akademisk fag som i århundrer har jobbet med argumenter for og mot ulike religiøse påstander. Dersom skoler ville lagt opp til noen dager i året som var viet til KRLE, ville det helt sikkert være mulig å invitere eksperter til å stille online for å svare på spørsmål på direkten eller på forhåndsinnsendte spørsmål.

Ideelt sett skulle det vært en kvalitetssikret nettside som samlet argumenter for og mot ulike påstander i religioner og livssyn, eller en sentral side som lenket til seriøse sider med argumenter for og mot ulike slike. Da skulle det være mulig for lærerne å orientere seg greit. Hvis det skulle bli $\emptyset \mathrm{kt}$ fokus på dette i skolen, ville det ikke være veldig krevende å lage en slik side.

Samtidig er det klart at det er snakk om store spørsmål, og om store temaer som til dels handler om virkeligheten som helhet, og hvor en velbegrunnet konklusjon ville krevet detaljert sammenligning av livssyn på tvers. Men også dette er en viktig innsikt - altså at det er krevende å gi en velbegrunnet vurdering av et livssyn. Altfor mange kommer ut av skolen med den oppfatning at religioner er håpløse tankekonstruksjoner som naturvitenskapen enkelt har motbevist. Jeg ser ikke bort fra at også mange religionslærere kunne hatt nytte av å måtte sette seg litt mer inn i kompleksiteten i grunner for og mot ulike livssynsoppfatninger. Jeg sier ikke at det ikke er krevende, men jeg tror at det er verdt strevet.

Når det gjelder nødvendig modenhet hos elever, har jeg ingen spesiell kompetanse på når man er moden nok til å diskutere religion, men har mye erfaring selv fra at det er svært givende og svært engasjerende med ungdom fra konfirmasjonsalder og oppover. Læreplanen til KRLE har religionskritikk som kompetansemål på 10. trinn, hvilket skulle tilsi at elever fra 8. til 10. trinn burde kunne være i stand til slik drøfting. Anliggendet i denne artikkelen er altså inne, men jeg har prøvd å argumentere for at det kan få større plass enn lærebøkene i dag synes å gi det. Evne til saklig diskusjon av følsomme spørsmål er det viktig å øve på allerede fra skolealder, uten at jeg har en sterk mening om akkurat når det skal begynne. En relevant parallell er at vi forventer at skoleungdom etter hvert skal kunne ta stilling til ulike politiske syn og ideologier, som er en nær parallell til andre livssyn og religioner. Hvis man skal kunne vurdere en politisk ideologi, burde man også kunne vurdere et livssyn generelt (Stenmark 2012: 111).

7 Tittelen på prosjektet er sannsynligvis inspirert av Lars Laird Iversens konsept om uenighetsfellesskap (Iversen 2014). 


\section{KonkLuSJon}

Denne gjennomgangen av argumenter har hatt til hensikt å gi en sammenhengende begrunnelse for at sannhetspretensjonen i religiøse påstander både kan og bør diskuteres i religionsfaget i skolen. Dette fordrer lærebøker og lærere som er i stand til å presentere saklige argumenter både for og mot alle de aktuelle livssyn og religioner som diskuteres. Kanskje er denne praktiske utfordringen i realiteten den største utfordringen. Som nevnt ovenfor finnes det nettressurser mens vi venter på noe bedre. Åpen og kritisk sannhetss $\varnothing$ ken er verdifullt i alle fag, og en slik tilnærming i religionsfaget burde kunne gi elever $\emptyset \mathrm{kt}$ mangfoldskompetanse og evne til å leve sammen på tvers av verdiuenigheter.

\section{LITTERATUR}

Bouras, M. (1996). Islams plass i skolen. I: L. G. Lingås \& L. London (red.), Likhet eller likeverd? En kritikk av det nye kristendomsfaget i grunnskolen (s. 62-70). Oslo: Humanist forlag.

Eikrem, A. (kommer). «Mystery is what faith essentially includes ... A philosophical critique of the semantic-ontological presuppositions of negative/mystical theology.» I: I. U. Dalferth \& M. R. Block (red.), The Meaning and Power of Negativity. Tübingen: Mohr Siebeck.

Engen, T. O. (1994). «Integrerende sosialisering i majoritetens skole?» I T. O. Engen, A.-M. Haugen, I. Morken, E. Ryen, \& G. Standnes (red.), Like muligheter? Migrasjonspedagogikk i majoritetens skole. (s. 145-170). Oslo: Ad Notam Gyldendal.

Flint, T. P., \& Rea, M. C. (2008). The Oxford handbook of philosophical theology. New York: Oxford University Press.

Gravem, P. (2004). KRL - et fag for alle? KRL-faget som svar på utfordringer i en flerkulturell enhetsskole. Vallset: Oplandske bokforlag.

Habermas, J. (2006). «Religion in the Public Sphere.» European Journal of Philosophy, $14(1), 1-25$.

Iversen, L. L. (2014). Uenighetsfellesskap: Blikk på demokratisk samhandling. Oslo: Universitetsforlaget.

Jackson, R. (1997). Religious Education. An Interpretive Approach. London: Hodder and Stoughton.

Jackson, R. (2004). Rethinking religious education and plurality. Issues in diversity and pedagogy. London: RoutledgeFalmer.

Kruger, J., \& Dunning, D. (1999). «Unskilled and Unaware of It. How Difficulties in Recognizing One's Own Incompetence Lead to Inflated Self-Assessments.» Journal of Personality and Social Psychology, 77(6), 1121-1134.

Kuhn, T. S. (1962). The structure of scientific revolutions. Chicago: University of Chicago Press. 
MacIntyre, A. C. (1988). Whose justice? Which rationality? Notre Dame, Ind.: University of Notre Dame Press.

Mele, A. R. (1995). Autonomous Agents. From Self-Control to Autonomy. New York: Oxford University Press.

Pannenberg, W. (1991). Systematic theology, vol. 1. Grand Rapids, MI: Eerdmans.

Parfit, D. (2011). On what matters. Oxford: Oxford University Press.

Puntel, L. B. (2008). Structure and Being. A Theoretical Framework for a Systematic Philosophy. University Park, PA: Pennsylvania State University Press.

Rorty, R. (1995). «Is Truth A Goal of Enquiry? Davidson Vs. Wright.» The Philosophical Quarterly, 45(180), 281-300.

Schjetne, E. (2014). «Kritisk blikk på kritikk. Religionskritikk som balansekunst i den offentlige skolen.» I: G. Afdal, Å. Røthing, \& E. Schjetne (red.), Empirisk etikk i pedagogiske praksiser. Artikulasjon, forstyrrelse, ekspansjon (s. 153-176). Oslo: Cappelen Damm Akademisk.

Skirbekk, G. (2011). «Religionskritikk - kvifor og korleis?» Religion og livssyn, 23(3), $12-16$.

Skrunes, N. (2010). Toleranselæring og læereboktekster. Oslo: Abstrakt forlag.

Spinner-Halev, J. (2000). Surviving diversity. Religion and democratic citizenship. Baltimore: Johns Hopkins University Press.

Stenmark, M. (2012). «Kan religiös tro vara rationell?» I O. Franck \& M. Stenmark (red.), Att undervisa om religion och vetenskap: med grund $i$ ämnesplanen för religionskunskap (s. 97-112). Lund: Studentlitteratur.

Stevenson, C. L. (1944). Ethics and language. New Haven: Yale University Press.

Wright, A. (2016). Religious education and critical realism. Knowledge, reality and religious literacy. London: Routledge, Taylor \& Francis Group. 